\title{
The hazard of old lead mines in Wales
}

\author{
H. F. THOMAS, F. MOORE, E. WELSBY, P. C. ELWOOD \\ From the MRC Epidemiology Unit (South Wales)
}

J. N. M. FIRTH

From the Welsh Office, Cardiff

SUMmaRY Two population surveys were conducted near old lead workings in Wales. The first, at Y Fan in the middle of Wales, gave evidence suggestive of a gradient in blood lead level, highest in subjects resident close to the contaminated spoil heaps, and lowest in those who lived in farms some distance away. However, the gradient was significant $(P<0.05)$ only in males, and all but one of the blood lead levels were below $2.0 \mu \mathrm{mol} / 1$. In the second survey, at Halkyn in North Wales, levels in subjects living in the area contaminated by spoil were compared with those in subjects living in a nearby industrial area, and with subjects in a market town some distance away. Mean blood lead levels in people living in the three areas were homogeneous. These studies give no evidence that old lead workings in Wales are a serious hazard to health.

Throughout Wales there are about 250 old lead workings. Most of these are in areas of outstanding natural beauty and although many are in remote places, some are close to human dwellings. They are usually surrounded by spoil heaps which are the residue of crushed ore and tailings produced during the separation of the lead from waste material. This waste is very finely crushed rock and usually contains between $1 \%$ and $4 \%$ lead and sometimes as much as $15 \%$ lead. Little vegetation grows on this and wind and water erosion can be rapid with spreading of the lead down wind and down stream. The spoil heaps therefore constitute a potential hazard to health. Many old workings were inspected and two with people living close to the spoil heaps were selected.

One of these workings was at $Y$ Fan in Powis near Llanidloes in mid Wales (map reference SN948876), an area of generally acidic soils. This mine was highly productive during the period 1870-90. About 96000 tonnes of lead had been produced and this is estimated to have required crushing over one million tonnes of rock (Morrison, 1971). All that remains now is about 16 hectares of crushed spoil containing about $4 \cdot 2 \%$ lead (Johnson et al., 1977). The site is in a small valley running from west to east, the prevailing wind and the flow of water being from the west. Detailed botanical and animal studies of lead and other metal pollutants have been conducted recently (Johnson et al., 1977, personal communication) and it seemed appropriate to extend this work to humans.
Within 200 metres to the east of the spoil heaps is a small terrace of 18 houses and about 10 other houses, some of which are used as holiday residences. Persons habitually resident in this area were judged to be at greatest risk of pollution and are referred to in what follows as 'near' the tips. About 20 dwellings are between approximately 200 and 500 metres from the spoil heaps, most on rising ground on either side of the valley. These were judged to be at a smaller risk of pollution and are termed the 'mid' group. Surrounding the village, but at a considerable distance from the tips, are other dwellings and residents in these were assumed to be at no appreciable risk of pollution from the spoil. About 12 such houses, mainly farms, were selected and residents in them are referred to as the 'far' group.

Lead mining at Halkyn (map reference SJ209705), the other area selected, began in Roman times but exploitation was at its greatest during the period from 1845 to 1938 (Lewis, 1967). The soils are generally alkaline. The area of mining was extensive and there are estimated to be about 600 old shafts. The spoil heaps are not well demarcated and soil analyses have shown extensive contamination of the whole area (Davies and Roberts, 1975). All residents in the area were judged to be at risk and for comparison two other populations were selected. These were Greenfield (map reference SJ195776) a local industrial area where lead had been smelted early this century, and Ruthin (map reference SJ124583) a market town 


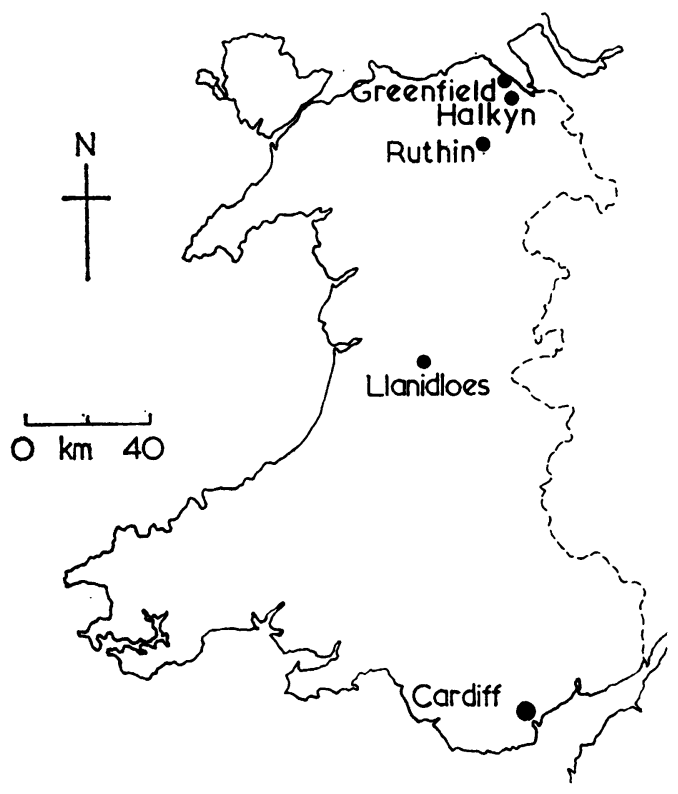

with no significant industry and no history of lead workings.

The locations of the areas studied are shown in the Figure.

\section{Methods}

At Y Fan, all subjects listed in the electoral roll at the addresses selected were written to and asked to co-operate. Children were subsequently identified and included. At Halkyn, Greenfield, and Ruthin random samples of 60,40 , and 40 respectively were selected from the electoral roll. No children were included.

In all areas only subjects who were habitually resident were included, and those who were only there on holiday and students studying away were excluded, as were two occupationally exposed subjects. A sample of venous blood was taken from each adult and capillary blood from each child for lead estimation by atomic absorption spectroscopy and for haemoglobin estimation. The former estimations were all made at a National Health Service supraregional laboratory in which the reproducibility of blood lead estimation had been found to be excellent (Beasley et al., 1974).

\section{Results}

At Y Fan 78 subjects over 18 years of age were seen out of a total of 99 in the houses selected. Thirteen of the omissions were in the group living farthest from the spoil heaps and only four in the area nearest to the tips were not seen. There were a few children (under 18 years of age) but we did not feel it justifiable to press for their examination. Three lived within the 'near' area but none of these was seen. Twelve children from the other areas were seen.

At Halkyn, Greenfield, and Ruthin the response rates, after excluding those who had moved away, etc., were $90 \%, 90 \%$, and $86 \%$ respectively.

Table 1 shows that there are differences in the age distributions of subjects in the three areas at Y Fan. These are significant in females but not in males,, with the subjects near the tips having the highest mean age in both sexes. Data for duration of residence indicate that the population is reasonablyo stable. The 'mid' areas have a lower mean for both sexes, but differences are significant only in males. The haemoglobin levels are unremarkable. The blood lead levels however show evidence in both sexes of a gradient, the highest levels being found in those living near the tips and in males, although not in females; these means show significant heterogeneity. All the mean levels however are low.

Table 2 summarises the data from the second survey. The groups are all stable with no significant differences in mean age or mean duration of residence. Only trivial differences occur in the mean haemoglobin levels. Again the mean blood lead levels are all low, and the differences which do occur are neither statistically significant nor do

Table 1 Numbers of subjects ( $n)$, mean ages, duration of residence, haemoglobin level $(\mathrm{Hb})$, and blood level (Pb) in subjects within areas defined by distance from lead tips at $Y$ Fan

\begin{tabular}{|c|c|c|c|c|c|c|}
\hline Area & $n$ & $\begin{array}{l}\text { Mean ages } \\
(\text { years })\end{array}$ & $\begin{array}{l}\text { Mean residence } \\
\text { (years) }\end{array}$ & $\begin{array}{l}\text { Mean } H b \\
(g / d l)\end{array}$ & $\frac{\text { Mean Pb }}{\mu \text { molll }}$ & $(\mu g / 100 \mathrm{ml})$ \\
\hline $\begin{array}{l}\text { Males } \\
\text { Near } \\
\text { Mid } \\
\text { Far }\end{array}$ & $\begin{array}{r}9 \\
18 \\
10\end{array}$ & $\begin{array}{l}57 \cdot 3 \\
39 \cdot 2 \\
49 \cdot 7\end{array}$ & $\begin{array}{l}31 \cdot 7 \\
17 \cdot 7 \\
38 \cdot 8\end{array}$ & $\begin{array}{l}15 \cdot 1 \\
15.0 \\
14.6\end{array}$ & $\begin{array}{l}1.06 \\
0.92 \\
0.73\end{array}$ & $\begin{array}{l}(21 \cdot 9) \\
(19 \cdot 0) \\
(15 \cdot 1)\end{array}$ \\
\hline $\begin{array}{c}\text { Females } \\
\text { Near } \\
\text { Mid } \\
\text { Far }\end{array}$ & $\begin{array}{l}14 \\
17 \\
10\end{array}$ & $\begin{array}{l}62 \cdot 1 \\
45 \cdot 8 \\
52 \cdot 2\end{array}$ & $\begin{array}{l}33.7 \\
19.4 \\
33.8\end{array}$ & $\begin{array}{l}13 \cdot 9 \\
13 \cdot 1 \\
14 \cdot 4\end{array}$ & $\begin{array}{l}0.81 \\
0.79 \\
0.62\end{array}$ & $\begin{array}{l}(16 \cdot 8) \\
(16 \cdot 4) \\
(12 \cdot 8)\end{array}$ \\
\hline
\end{tabular}

Analyses of variance show significant heterogeneity of means for blood lead levels and duration of residence in males and for age in females. 
Table 2 Number of subjects $(n)$, mean ages, duration of residence, haemoglobin level $(\mathrm{H} b)$, and blood level (Pb) in subjects at Halkyn, Greenfield, and Ruthin

\begin{tabular}{|c|c|c|c|c|c|c|}
\hline Area & $n$ & $\begin{array}{l}\text { Mean ages } \\
\text { (years) }\end{array}$ & $\begin{array}{l}\text { Mean residence } \\
\text { (years) }\end{array}$ & $\underset{(g / d l)}{\operatorname{Mean} H b}$ & $\frac{\text { Mean } P}{\mu m o l l l}$ & $(\mu \mathrm{g} / 100 \mathrm{ml})$ \\
\hline $\begin{array}{l}\text { Males } \\
\text { Halkyn } \\
\text { Greenfield } \\
\text { Ruthin }\end{array}$ & $\begin{array}{l}19 \\
12 \\
17\end{array}$ & $\begin{array}{l}46 \cdot 1 \\
39 \cdot 2 \\
50 \cdot 1\end{array}$ & $\begin{array}{l}26 \cdot 3 \\
24 \cdot 6 \\
28 \cdot 9\end{array}$ & $\begin{array}{l}14 \cdot 9 \\
15 \cdot 3 \\
15 \cdot 1\end{array}$ & $\begin{array}{l}0.91 \\
0.90 \\
1.02\end{array}$ & $\begin{array}{l}(18 \cdot 7) \\
(18 \cdot 6) \\
(21 \cdot 1)\end{array}$ \\
\hline $\begin{array}{l}\text { Females } \\
\text { Halkyn } \\
\text { Greenfield } \\
\text { Ruthin }\end{array}$ & $\begin{array}{l}22 \\
17 \\
18\end{array}$ & $\begin{array}{l}48 \cdot 6 \\
44 \cdot 3 \\
58 \cdot 3\end{array}$ & $\begin{array}{l}40 \cdot 4 \\
37 \cdot 2 \\
36 \cdot 7\end{array}$ & $\begin{array}{l}13 \cdot 3 \\
13 \cdot 2 \\
13 \cdot 2\end{array}$ & $\begin{array}{l}0.77 \\
0.68 \\
0.65\end{array}$ & $\begin{array}{l}(15 \cdot 9) \\
(14 \cdot 1) \\
(13 \cdot 5)\end{array}$ \\
\hline
\end{tabular}

they give any evidence consistent with a hazard at Halkyn.

Tables 3 and 4 set out the distributions of blood lead levels. Only two subjects, a woman in the 'mid' area at $Y$ Fan, and a man in Ruthin, had levels above $2 \mu \mathrm{mol} / \mathrm{l}(41 \mu \mathrm{g} / 100 \mathrm{ml})$.

The results for children at $Y$ Fan are shown in Table 5. These were all low.

Table 3 Distribution of blood lead levels at Y Fan

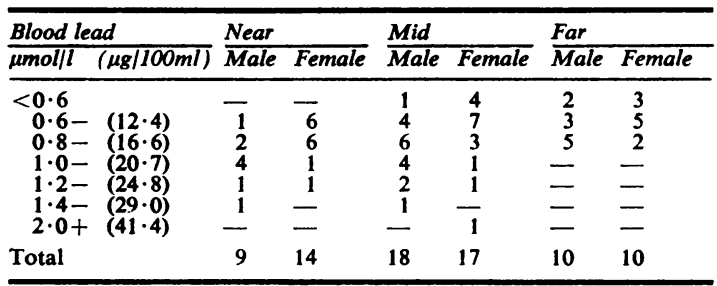

Table 4 Distribution of blood lead levels at Halkyn, Greenfield, and Ruthin

\begin{tabular}{|c|c|c|c|c|c|c|c|}
\hline \multicolumn{2}{|c|}{ Blood lead } & \multicolumn{2}{|c|}{ Halkyn } & \multicolumn{2}{|c|}{ Greenfield } & \multicolumn{2}{|l|}{ Ruthin } \\
\hline$\mu \mathrm{mol} / \mathrm{l}$ & $(\mu \mathrm{g} / 100 \mathrm{ml})$ & Male & Female & Male & Female & $\overline{\text { Male }}$ & Female \\
\hline $\begin{array}{l}0.6 \\
0.6- \\
0.8- \\
1.0- \\
1 \cdot 2- \\
1.4- \\
2.0+\end{array}$ & $\begin{array}{l}(12 \cdot 4) \\
(16 \cdot 6) \\
(20 \cdot 7) \\
(24 \cdot 8) \\
(29 \cdot 0) \\
(41 \cdot 4)\end{array}$ & $\begin{array}{l}-4 \\
7 \\
6 \\
1 \\
1 \\
-\end{array}$ & $\begin{array}{l}6 \\
6 \\
5 \\
3 \\
1 \\
1 \\
-\end{array}$ & $\begin{array}{l}-3 \\
6 \\
1 \\
1 \\
1 \\
-\end{array}$ & $\begin{array}{l}5 \\
6 \\
3 \\
3 \\
- \\
-\end{array}$ & $\begin{array}{l}-3 \\
6 \\
4 \\
2 \\
1 \\
1\end{array}$ & $\begin{array}{r}3 \\
12 \\
3 \\
- \\
- \\
-\end{array}$ \\
\hline Total & & 19 & 22 & 12 & 17 & 17 & 18 \\
\hline
\end{tabular}

Table 5 Sex, age, and capillary blood levels $(\mathrm{Pb})$ of children in far and mid areas

\begin{tabular}{|c|c|c|c|c|c|}
\hline \multirow[b]{2}{*}{ Area } & \multirow[b]{2}{*}{ Case no. } & \multirow[b]{2}{*}{ Sex } & \multirow[b]{2}{*}{$\begin{array}{l}\text { Age } \\
\text { (years) }\end{array}$} & \multicolumn{2}{|c|}{ Blood lead } \\
\hline & & & & umol/l & $\mu \mathrm{g} / 100 \mathrm{ml}$ \\
\hline Far & $\begin{array}{l}95 \\
86 \\
85 \\
84 \\
82 \\
81 \\
50\end{array}$ & $\begin{array}{l}\text { Boy } \\
\text { Boy } \\
\text { Boy } \\
\text { Girl } \\
\text { Girl } \\
\text { Girl } \\
\text { Girl }\end{array}$ & $\begin{array}{r}16 \\
8 \\
12 \\
13 \\
10 \\
11 \\
6\end{array}$ & $\begin{array}{l}0 \cdot 8 \\
1 \cdot 2 \\
1 \cdot 1 \\
0 \cdot 8 \\
0 \cdot 6 \\
0 \cdot 7 \\
1 \cdot 0\end{array}$ & $\begin{array}{l}(16 \cdot 6) \\
(24 \cdot 8) \\
(22 \cdot 8) \\
(16 \cdot 6) \\
(12 \cdot 4) \\
(14 \cdot 5) \\
(20 \cdot 7)\end{array}$ \\
\hline Mid & $\begin{array}{l}40 \\
35 \\
34 \\
33 \\
28\end{array}$ & $\begin{array}{l}\text { Girl } \\
\text { Boy } \\
\text { Boy } \\
\text { Boy } \\
\text { Girl }\end{array}$ & $\begin{array}{r}14 \\
7 \\
10 \\
13 \\
5\end{array}$ & $\begin{array}{l}0.6 \\
1 \cdot 1 \\
1 \cdot 0 \\
0 \cdot 8 \\
0.7\end{array}$ & $\begin{array}{l}(12 \cdot 4) \\
(22 \cdot 8) \\
(20 \cdot 7) \\
(16 \cdot 6) \\
(14 \cdot 5)\end{array}$ \\
\hline
\end{tabular}

\section{Discussion}

Neither of these surveys gives any evidence suggestive of a serious hazard to health from old lead workings. Nevertheless the data from Y Fan give some evidence that lead from the spoil heaps can get into the blood of residents in the immediate vicinity. The gradient detected in blood lead levels is slight however, and in view of the generally low levels it appears unlikely that these old lead workings are a serious hazard to the health of local residents.

Serious bias in the data seems unlikely. The populations are stable and high response rates were obtained in the groups at highest risk. Regression analyses showed that the effects of age and duration of residence on blood lead are trivial and could have had, at most, only a very small effect on mean lead levels.

The number of children seen was small and none was from the area at greatest risk. Our data are therefore limited and it could be that children who play on the spoil heaps are at risk of inhaling or ingesting lead.

With this one possible exception, the results of these two surveys are consistent with the findings of Barltrop et al. (1974) who judged that local soil lead levels of the order of $10000 \mathrm{ppm}(1 \%)$ are without major significance to health.

We should like to thank the community physicians and Mr V. Clarke, Secretary of the Halkyn Residents Association, for giving every possible assistance to this work. We are also most grateful to P. M. E. Broughton and Marion Sheltawy for doing the blood lead estimations.

Reprints from P. C. Elwood, MRC Epidemiology Unit (South Wales), 4 Richmond Road, Cardiff CF2 3AS.

\section{References}

Barltrop, D., Strehlow, C. D., Thornton, I., and Webb, J. S. (1974). Significance of high soil lead concentrations 
for childhood lead burdens. Environmental Health Perspectives, 7, 75-82.

Beasley, W. H., Broughton, P. M. E., Delves, H. T., and Elwood, P. C. (1974). Letter: Blood lead levels in Aberystwyth. British Medical Journal, 1, 576.

Davies, B. E., and Roberts, L. J. (1975). Heavy metals in soils and radish in a mineralised limestone area of Wales, Great Britain. Science of the Total Environment, 4, 249-261.
Johnson, M. S., McNeilly, T., and Putwain, P. D. (1977). Revegetation of metalliferous mine spoil contaminated by lead and zinc. Environmental Pollution (London), 12, 261-277.

Lewis, W. J. (1967). Lead Mining in Wales. University of Wales Press: Cardiff.

Morrison, T. A. (1971). Some notes on the Van mine, Llanidloes, Montgomery. Industrial Archaeology (Edinburgh), 8, 29-51. 